\title{
NASIONALISME ELIT PEMUDA DI PROVINSI RIAU
}

\author{
Bahjatul Murtasidin \& Alfajri \\ Program Studi Ilmu Pemerintahan, Universitas Abdurrab \\ Program Studi IImu Hubungan Internasional, Universitas Abdurrab \\ JI. Riau Ujung, No. 73 Pekanbaru, 28292, Indonesia \\ email: bahjatul.murtasidin@univrab.ac.id
}

\begin{abstract}
Abstrak
Nasionalisme bangsa dalam ancaman manakala kaum mudanya begitu terlalaikan dengan segala gemerlap teknologi akibat arus globalisasi. Berada di bawah gemerlap teknologi bisa jadi menghasilkan gelembung-gelembung delusi persepsi yang memudarkan rasa cinta tanah air. Begitulah kiranya sisi buruk yang timbul akibat globalisasi walaupun sebenarnya nasionalisme dan globalisasi bukanalah sebuah konsep oksimoron. Akan tetapi, akibat kondisi geografis yang langsung berhadapan dengan dua benua dan dua samudra, konsep oksimoron menjadi realita yang menjadi ujian nyata bagi nasionalisme elit pemuda di Provisi Riau. Penelitian ini dilakukan dengan menggunakan pendekatan kualitatif dengan metode survei. Survei dilakukan terhadap elit organisasi kepemudaan di Provinsi Riau dan beberapa daerah Kab/Kota. Penelitian ini diharapkan menjadi poin rekomendasi kepada pemerintah dalam merumuskan kebijakan kepemudaan dan organisasi kepemudaan dalam upaya meningkatkan dan mengaktualisasikan nasionalisme dikalangan pemuda.
\end{abstract}

Kata kunci: nasionlisme, elit pemuda, Riau

\begin{abstract}
Nationalism is under a threat when its young men are unaware of negative impacts from globalization and technological development. Massive development of sophisticated technology to some extent can decrease the way the youth loves their country. Perhaps, that is one of negative effects of globalization although nationalism and globalization are not an oxymoron concept. Nevertheless, Indonesia's geographical location that lies between two oceans and continents, the oxymoron concept becomes a reality challenging nationalism of youth's elite in Riau. This research is conducted by a qualitative approach using survey to collect primary data. Survey was carried by distributing questionnaire to youth's organizations in Riau. This research is expected to give recommendation to government in formulating policies on youth and its organizations in order to actualize the feeling of nationalism.
\end{abstract}

Keywords: nationalism, youth's elite, Riau

\section{PENDAHULUAN}

Apabila berbicara tentang pemuda, maka kita berbicara tentang kekuatan dan semangat yang begitu besar untuk perubahan (Aspian 2014). Mengapa demikian? Pertama, secara kuantitatif, jumlah pemuda Indonesia (tahun 2014) sebanyak 61,83 juta jiwa atau sekitar 24,53 persen dari 252,04 juta jiwa penduduk Indonesia (Kemenpora RI 2015). Dengan jumlah pemuda yang secara kuantitif potensial ini, maka kelompok pemuda merupakan subjek sekaligus objek pembangunan yang penting. Kedua, pemuda memiliki jiwa yang tangguh dan semangat yang tinggi (nasionalisme) dalam memperjuangkan revolusi dan renovasi peradaban bangsanya menuju arah yang 
lebih baik. Mereka (pemuda) bergerak atas nilai-nilai idealisme dan moralitas dalam melihat persoalan yang ada demi tercapainya kesejahteraan bangsanya (Aspian 2014). Ketiga, pemuda (dalam konteks pelaksanaan otonomi daerah) merupakan aset daerah yang sangat berharga kiprahnya menuju terciptanya pemerintahan yang baik (Abdul Syakur 2008). Keempat, sejarah telah mengungkapkan fakta dengan jujur bahwa pemuda merupakan pelopor perubahan dan kemajuan karena jiwa nasionalisme yang melekat padanya. Berbagai perubahan yang terjadi disuatu negara (termasuk perjuangan kemerdekaan Bangsa Indonesia), pemudalah penggerakknya. Bahkan, tentang kehebatan pemuda, Allah SWT telah mengisahkannya dalam Al-Qur'an (Surat Al-Kahfi). Selain itu, dalam sebuah hadits yang diriwayatkan oleh Muttafaqun'alaihi juga disebutkan bahwa pemuda merupakan salah satu dari tujuh golongan yang akan mendapatkan perlindungan dalam hari Kiamat.

Fakta di atas menunjukan bahwa pemuda menempati posisi yang sangat strategis, yang mampu menciptakan hal-hal luar biasa termasuk faktor perubahan yang fundamental. Akan tetapi, seiring dampak globalisasi yang kian nyata menerpa bangsa bangsa (dalam kondisi bangsa yang kurang stabil dan terarah), kerapkali terdengar suara yang meragukan integritas, kapasitas, dan kapabilitas pemuda dalam menopang bangsa dan negara dalam menghadapi zaman sebagaimana fakta sejarah dari peran pemuda yang telah diuraikan di atas. Selain itu, nilai dan pandangan hidup pemuda Indonesia dinilai terlalu konservatif atau bahkan terlalu liberal sehingga dapat membahayakan kondisi negara. setidaknya menjadi sumber permasalahan yang dapat menghambat kemajuan bangsa.

Penilaian yang cukup mengkhawatirkan adalah mulai diragukannya nasionalisme pemuda Indonesia. Mereka dinilai mulai kehilangan kebanggan pada negaranya dan terpengaruh dengan budaya asing. Padahal, nasionalisme merupakan perisai yang dapat mengantisipasi dampak globalisasi dan semakin menghilangnya identitas sebuah bangsa. (Arif Musthofa 2011)

Jika globalisasi telah menyebabkan hilangnya kebanggaan pada negaranya dan mulai diragukannya nasionalisme pemuda, bagaimana dengan nasionalisme pemuda di Provinsi Riau? Apakah sikap nasionalisme pemuda di Riau juga perlu untuk diragukan? 
Pertanyaan ini penting untuk ditemukan jawabannya dengan alasan bahwa: pertama, jika dilihat dari sudut pandang geografis, pemuda di Riau lebih berat tantangannya dalam menghadapi arus globalisasi karena Provinsi Riau berhadapan langsung dengan Selat Malaka dan beberapa negara (Malaysia dan Singapura). Kedua, isu-isu nasional (seperti isu sara, penistaan agama, separatisme, bahkan yang lebih ekstrim lagi isu bangkitnya PKI dan isu upaya menggantikan Ideologi Pancasila sebagai Ideolgi Bangsa) yang sedang marak menjadi perdebatan dikalangan masyarakat akhir-akhir ini, tidak terkecuali dikalangan pemuda. Oleh karena itu, penting untuk dilakukan sebuah penelitian tentang bagaimana sikap nasionalisme pemuda di Provinsi Riau.

\section{TINJAUAN PUSTAKA}

Kajian terdahulu secara kepustakaan menempati posisi penting dari dari hasil penelitian karena penelitian terdahulu memberikan gambaran awal yang kuat mengapa sebuah penelitian harus dilakukan dan apa saja penelitian-penelitian lain yang telah dilakukan. Arip Musthopa (2011) meletakan keraguan atas integritas, kapasitas, dan kapabilitas pemuda dalam menopang bangsa dan negara dalam mengahadapi perubahan zaman sebagai pisau analisis dalam mengkaji nasionalisme elit pemuda. Keraguan nasionalisme di kalangan pemuda merupakan persoalan krusial yang semakin kuat muncul ke permukaan pada era kontemporer. Penilaian-penenilaian menurut Arif Musthopa ini belum tentu benar karena terdapat beragam potret pemahaman, pandangan, dan manifestasi nasionalisme dalam tubuh pemuda Indonesia dengan intensitasnya masing-masing. Keragaman serta intensitasnya tersebut penting untuk dideskripsikan dahulu untuk mempermudah perumusan langkah atau kebijakan yang relevan untuk pengembangan kepemudaan ke depan. Oleh karena itu, menurut Arif Musthopa perlu dilakukan sebuah survei dan penelitian guna mendeskripsikan bagaimana sesungguhnya nasionalisme dipahami oleh pemuda Indonesia dan bagaimana pandangan nasionalisme mereka. Khususnya nasionalisme yang tergambar pada elit pemuda karena peran mereka mampu mempengaruhi dan mengarahkan pemuda non-elit atau yang lainnya pada masa sekarang atau akan datang. 
Untuk menjawab pertanyaan tersebut, Arip Musthopa melakukan survei yang difokuskan pada pemahaman dan pandangan nasionalisme elit pemuda (yang tergabung di dalam Organisasi Kepemudaan) di 33 ibukota provinsi, dengan metode kuantitatif. Jumlah organisasi kepemudaan yang di survei berjumlah 106 (seratus enam) organisasi kepemudaan. Adapun temuan dari survei dan penelitian yang dilakukan adalah: pertama, potret nasionalisme pemuda yang masih kuat diperlihatkan oleh elit pemuda Indonesia. Hal ini tentu memunculkan suatu optimisme bahawa generasi muda Indonesia masih memiliki rasa nasionalisme yang tinggi. Kedua, nasionalisme elit pemuda Indonesia dibayang-bayangi oleh sejumlah kondisi yang mengancam bangsa dan negaranya juga nasionalismenya.

\section{Konsep Nasionalisme}

Istilah nasionalisme yang telah diserap ke dalam bahasa Indonesia menurut Boyd Shafer (1955) memiliki beragam pengertian, tergantung pada kondisi objektif dan subjektif dari setiap bangsa. Oleh sebab itu nasionalisme dapat bermakna sebagai berikut:

1. Nasionalisme adalah rasa cinta pada tanah air, ras, bahasa atau budaya yang sama, maka dalam hal ini nasionalisme sama dengan patriotisme.

2. Nasionalisme adalah suatu keinginan akan kemerdekaan politik, keselamatan dan prestise bangsa.

3. Nasionalisme adalah suatu kebaktian mistis terhadap organisme sosial yang kabur, kadang-kadang bahkan adikodrati yang disebut sebagai bangsa atau Volk yang kesatuannya lebih unggul daripada bagian-bagiannya.

4. Nasionalisme adalah dogma yang mengajarkan bahwa individu hanya hidup untuk bangsa dan bangsa demi bangsa itu sendiri.

5. Nasionalisme adalah doktrin yang menyatakan bahwa bangsanya sendiri harus dominan atau tertinggi di antara bangsa-bangsa lain dan harus bertindak agresif.

Walaupun terdapat beragam definisi tentang nasionalisme, Hans Kohn (1971) menggarisbawahi bahwa esensi nasionalisme adalah sama, yaitu " a state of mind, in 
which the supreme loyality of the individual is felt to be due the nation state" (sikap mental, dimana kesetiaan tertinggi dirasakan sudah selayaknya diserahkan kepada negara bangsa). Definisi ini menyiratkan bahwa inti dari nasionalisme adalah soal rasa dan kesetiaan. Kesamaan bahasa, kebudayaan dan wilayah hanya menjadi alat, sementara kesamaan cita-cita dan tujuan merupakan implikasi dari persamaan rasa dan kesetiaan. Meskipun ada perbedaan kebudayaan, bahasa dan wilayah namun semua itu dapat terlampaui jika ada kesamaan rasa dan kesetiaan, demikian sebaliknya. Kesamaan rasa dan kesetiaan ini pula yang pada ujungnya dapat melahirkan kesamaan cita-cita dan tujuan.

Soekarno dalam pidatonya di depan Sidang Umum PBB mengatakan bahwa nasionalisme merupakan kekuatan yang dapat membakar dan menimbulkan hasrat untuk kemerdekaan (Arif Musthofa 2011). Dengan nasionalisme ini bangsa Indonesia dapat mempertahankan hidupnya, memberi kekuatan sepanjang kegelapan penjajahan yang lama, dan selama berkobarnya perjuangan kemerdekaan. Dewasa ini kekuatan yang membakar itu masih tetap menyala-nyala di dada bangsa Indonesia dan tetap memberi kekuatan hidup bangsa (Saksono 2007). Dari pendapat ini, dapat disimpulkan bahwa pada hakikatnya, nasionalisme merupakan perpaduan atau sinergi dari rasa kebangsaan dan paham kebangsaan. Kondisi nasionalisme suatu bangsa akan terpancar dari kualitas dan ketangguhan bangsa tersebut dalam menghadapi berbagai ancaman. Dengan nasionalisme yang tinggi, kekhawatiran akan terjadinya ancaman terhadap keutuhan dan kesatuan bangsa akan dapat dielakkan. Dari nasionalisme akan mengalir rasa kesetiakawanan sosial, semangat rela berkorban dan dapat menumbuhkan jiwa patriotisme (Joned Bangkit Wahyu Laksono 2013).

\section{Konsep Pemuda}

Pemuda merupakan sebuah kata yang memiliki banyak makna. Dikotomi pemuda ini timbul akibat siapa sebenarnya yang pantas di sebut pemuda, atau apakah pemuda itu identik dengan semangat atau usia. Dari sisi usia, tidak ada definisi yag baku untuk menunjuk siapa sebetulnya individu yang termasuk pemuda. Menurut WHO dalam Sarlito Sarwono (2008) usia 10-24 tahun digolongkan sebagai young people, 
sedangkan remaja atau adolescence dalam golongan usia10-19 tahun. Sedangkan di Indonesia, yang dimaksud dengan pemuda adalah warga negara Indonesia yang memasuki periode penting pertumbuhan dan perkembangan yang berusia 16 (enam belas) sampai 30 (tiga puluh) tahun (dalam Undang-Undang Nomor 40 Tahun 2009 tentang kepemudaan pasal 1 ayat 1 ).

Jika dilihat dari aspek semangat, pemuda adalah individu yang bila dilihat secara fisik sedang mengalami perkembangan dan secara psikis sedang mengalami perkembangan emosional, sehingga pemuda merupakan sumber daya manusia yang akan menggantikan generasi sebelumnya, memiliki karakter yang dinamis, bahkan bergejolak dan optimis namun belum memiliki pengendalian emosi yang stabil.

\section{METODE}

Pendekatan penelitian yang digunakan dalam penelitian ini adalah pendekatan kualitatif (qualitative research). Penulis secara acak menyebarkan angket/kuisioner terhadap elit pemuda (pengurus KNPI) di 12 kabupaten/kota se-provinsi Riau dimana penekanan utama adalah wilayah terluar atau yang berbatasan langsung dengan Selat Malaka. Populasi dalam survey yang tersebar di 12 kabupaten/kota adalah elit pemuda (pengurus inti KNPI). Penelitian ini adalah penelitian deskriptif, dengan lebih banyak bersifat uraian dari hasil wawancara. Data yang telah diperoleh akan dianalisis secara kualitatif serta diuraikan dalam bentuk deskriptif.

\section{PEMBAHASAN}

Nasionalisme secara etimologi berasal dari kata "nasional" dan "isme" yaitu paham kebangsaan yang mengandung makna kesadaran dan semangat cinta tanah air, memiliki kebanggaan sebagai bangsa, atau memelihara kehormatan bangsa, memiliki rasa solidaritas terhadap musibah dan kekurangberuntungan saudara setanah air, sebangsa dan senegara serta menjunjung tinggi nilai persatuan dan kesatuan. Oleh karena itu, nasionalisme merupakan kata yang sering muncul ketika membahas tentang sejarah kemerdekaan di Indonesia. 
Nasionalisme lahir dengan bermacam-macam cara, mulai dari karena kesamaan akan sejarah, kebudayaan, cita-cita, ketidakadilan, penindasan, serta sebagai wujud perlawanan suatu kelompok bangsa (Marvin Perry 2013). Bagaimanapun cara lahirnya nasionalisme, yang jelas ia tidak lahir dengan sendirinya tanpa proses ideologis, politis, dan sosiologis. Hanya saja karena nasionalisme merupakan produk modernitas, maka perkembangan nasionalisme berada di titik persinggungan antara politik, teknologi, dan transfomasi sosial. Akibatnya, nasionalisme tidak dapat dilihat dari satu sisi saja, ia mesti dilihat secara komprehensif, sebagaimana menurut Boyd Shafer (1955) yang sudah penulis tulis sebelumnya pada konsep nasionalisme.

\section{Potret Nasionalisme Elit Pemuda di Provinsi Riau}

Beberapa temuan dari penelitian ini memberikan gambaran kepada kita bagaimana potret nasionalisme elit pemuda di Provinsi Riau di tengah ancaman rapuhnya spirit rasa kebangsaan Indonesia akibat arus globalisasi. Perlu penulis tegaskan kembali bahwa nasionalisme dalam penelitian ini dimaknai sebagai nilai-nilai kebangsaan yang membentuk sistem berfikir, sistem kepercayaan, atau serangkaian kerangka normatif untuk diperjuangkan, yang menyediakan sumber alasan untuk suatu program dan tindakan politik, bahkan suatu pengorbanan yang menuntut pembenaran tertentu. Selanjutnya, dalam konteks Indonesia, nasionalisme sangat erat kaitannya dengan pemahaman dan pandangan bangsa Indonesia atas empat pilar penting nasionalisme Indonesia, yakni Pancasila, UUD 1945, NKRI, dan Bhineka Tunggal Ika. Penelitian ini kemudian menggali pemahaman dan pandangan elit pemuda atas empat pilar di atas yang di operasikan dalam sejumlah isu dan pertanyaan yang terkait dengan kandungan empat pilar tersebut.

Berdasarkan temuan penelitian, elit pemuda di Provinsi Riau yang menyatakan bahwa Pancasila tetap sebagai pegangan hidup masyarakat Indonesia sebanyak 61 , $86 \%$ dan merupakan ideologi yang terbuka sebanyak $28,87 \%$. Sisanya $9,28 \%$ menyatakan bahwa Pancasila hanyalah sebagai falsafah/pegangan hidup dan bukan sebagai ideologi tertinggi di Indonesia. 


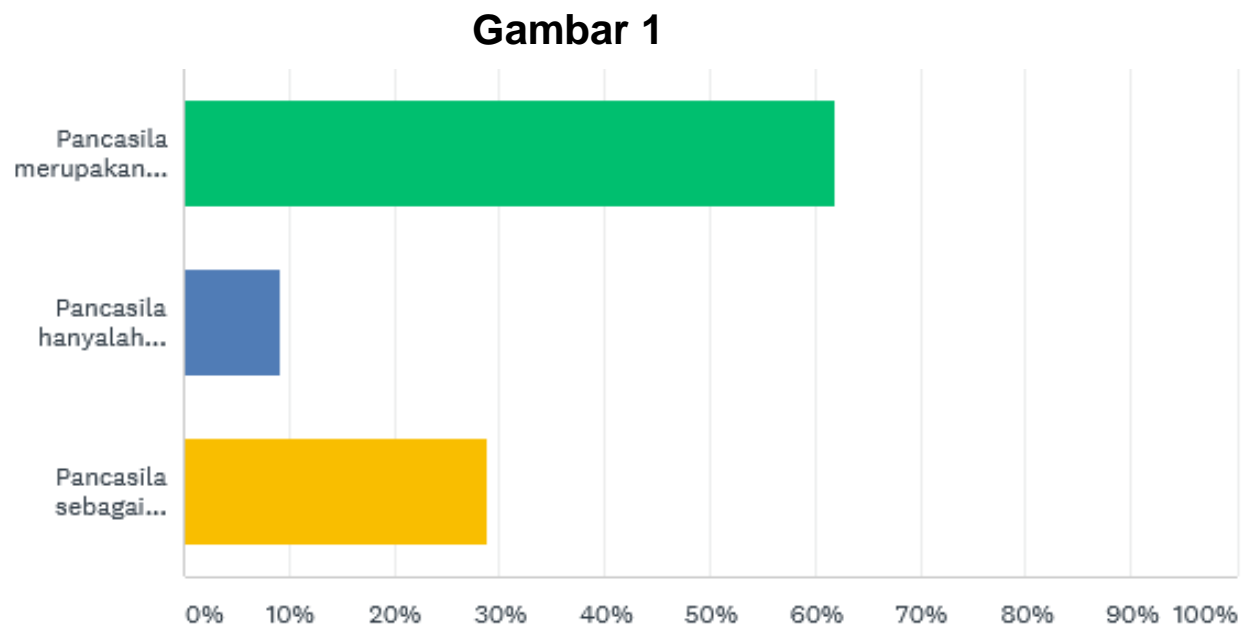

Sumber: olahan data penulis

Selain itu, Pancasila juga dipahami sebagai ideologi yang senantiasa relevan dengan kondisi saat ini $(75 \%)$.

\section{Gambar 2}

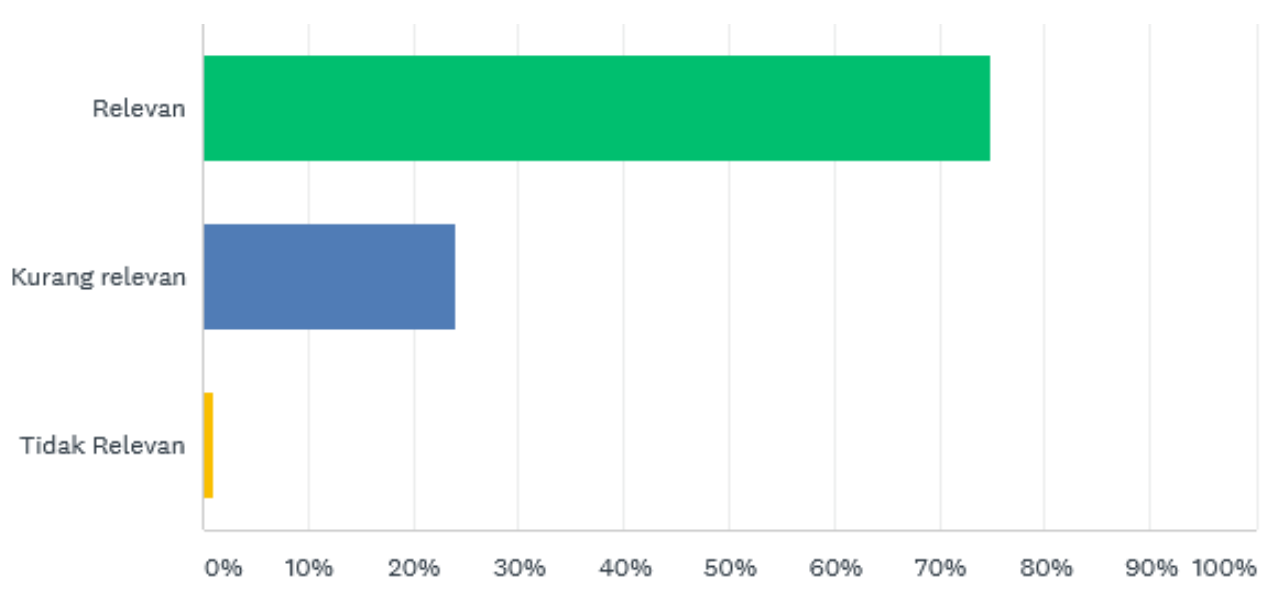

Sumber: olahan data penulis

Gambaran ini tentu bermakna positif karena pandangan dan pemahaman elit pemuda di Provinsi Riau terkait dengan Pancasila tidak perlu untuk diragukan. Sejak awak para founding fathers kita merumuskan Pancasila secara dialektis dan mengharapkan aktualisasi Pancasila dapat dilakukan secara dinamis. 
Selain itu, rasa cinta tanah air yang di representasikan melalui bendera sebagai simbol negara juga tinggi (70,32 \%). Elit pemuda marah dan sangat kesal ketika bendera sebagai simbol negara tidak dikibarkan pada saat peringatan hari kemerdekaan Indonesia di Provinsi Riau.

\section{Gambar 3}

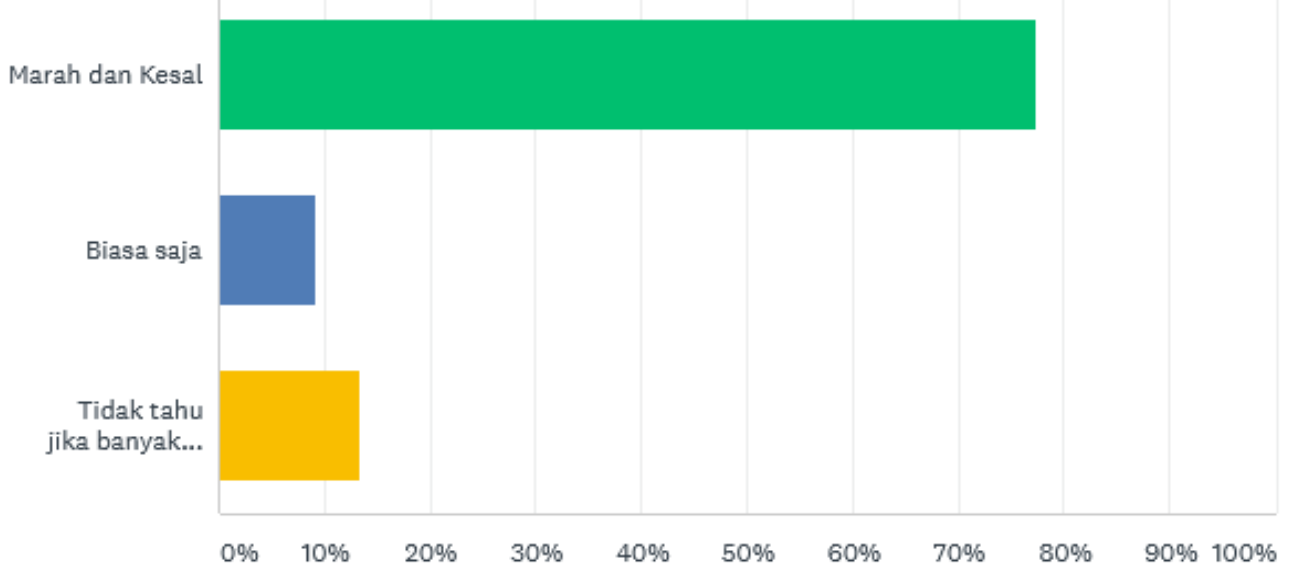

Sumber: olahan data penulis

Nasionalisme membuat suatu negara-bangsa memiliki kekuatan dan kegigihan sentimen dan identitas nasional (B. Anderson 1991). Identitas nasional ini dapat dibangun dan terus dikuatkan melalui berbagai macam cara, seperti dengan menanamkan gairah dan emosi-emosi mendalam di kalangan pengikutnya melalui simbol. Simbol-simbol tersebut dapat berupa bendera nasional, lambang negara, lagu kebangsaan atau semboyan nasional. Nasionalisme mengklaim bahwa simbol-simbol itu sangat penting dan menyatakan bahwa simbol-simbol tersebut merepresentasikan negara-bangsa. Sebagai representasi negara, maka cara memperlakukan simbolsimbol tersebut diatur dalam undang-undang. Perlakuan yang salah atau tidak pada tempatnya dapat dianggap sebagai penghinaan kepada negara.

Jika rasa cinta tanah air yang di representasikan melalui bendera sebagai simbol negara di Provinsi Riau sangat tinggi, hal ini agak berbeda ketika di hadapakan pada pendapat elit pemuda di Provinsi Riau terkait dengan Dana Bagi Hasil (DBH) yang diberikan oleh Pemerintah Pusat setiap tahun. Sebanyak 65,63 \% elit Pemuda di Provinsi Riau merasa tidak setuju/tidak puas dengan Dana Bagi Hasil yang di berikan. 
Hanya sekitar 16,67 \% elit pemuda yang setuju dan sisanya sebanyak 17,71 \% merasa biasa saja.

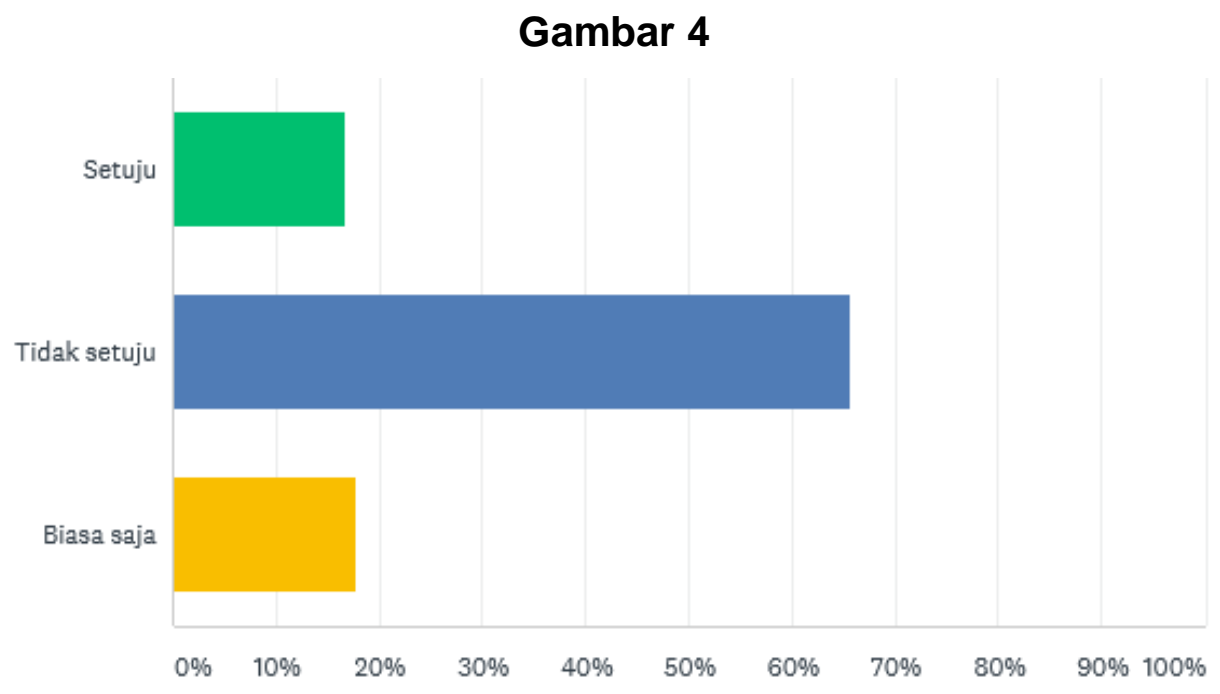

Sumber: olahan data penulis

Yang menjadi temuan menarik adalah sebagai konsekuensi dari rasa tidak puas/tidak terima dengan Dana Bagi Hasil yang diberikan oleh Pemerintah Pusat, generasi muda di Riau melalui elit pemudanya merasa siap dan mampu jika Minyak dan Gas (Migas) dan kekayaan alam lainnya dikelola sendiri oleh putra putri terbaik Provinsi Riau. Sebanyak $69,07 \%$ elit pemuda menyatakan siap atau mampu, sedangkan yang menyatakan belum siap sebanyak 29,90\%.

\section{Gambar 5}

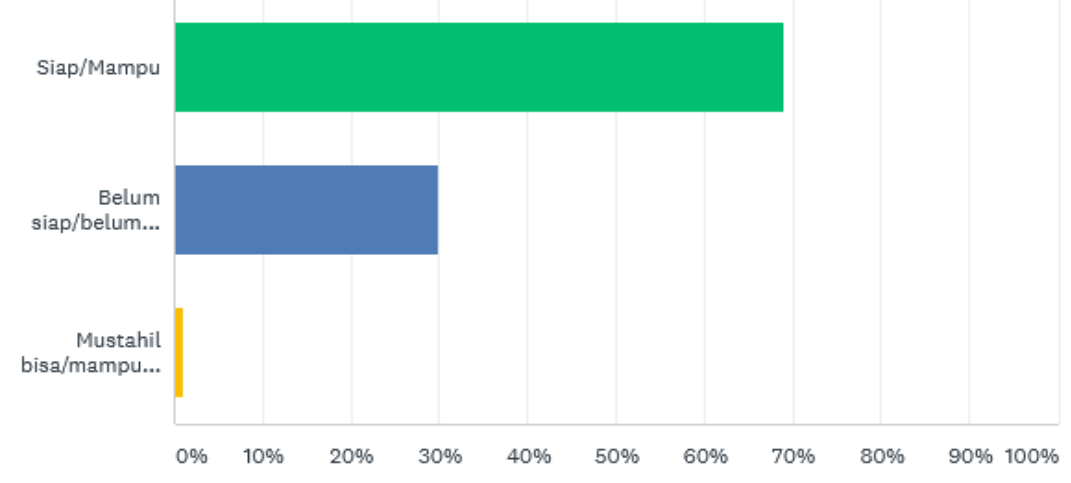

Sumber: olahan data penulis 
Pandangan yang lebih keras di tujukan oleh elit pemuda terhadap permasalahan kehadiran perusahaan asing di Provinsi Riau. Sebanyak 71,88 menyakatan tidak setuju atas berdirinya perusahaan asing di Provinsi Riau. Elit pemuda kurang "happy" dengan kehadiran perusahaan-perusahaan asing baik karena argumentasi tentang ancaman kapitalisme global maupun banyak merugikan Provinsi Riau. Oleh karena itu, elit pemuda setuju jika ada wacana nasionalisasi perusahaan asing di Provinsi Riau.

\section{Gambar 6}

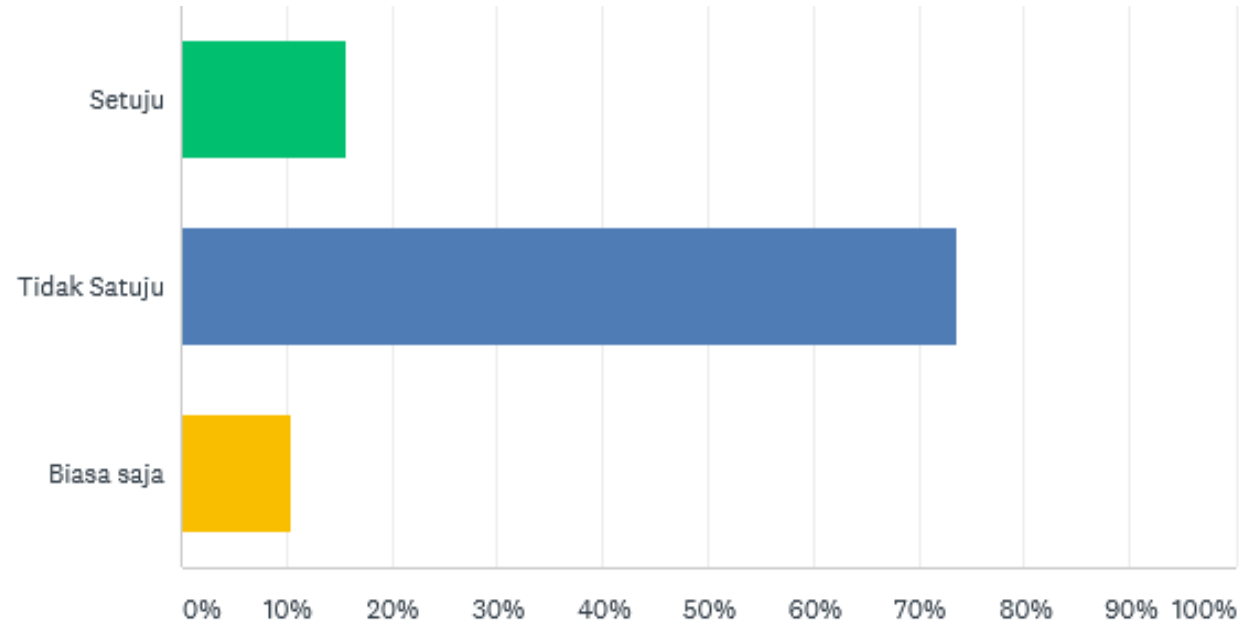

Sumber: olahan data penulis

Potret nasionalisme yang kuat dan meyakinkan diperlihatkan oleh elit pemuda di Provinsi Riau. Sebanyak 98.97 \% elit pemuda sangat bangga menggunakan produk asli buatan Indonesia. Sisi nasionalisme menyebabkan seseorang lebih mengedepankan pemakaian produk dalam negeri dibanding produk impor yang menjadi alternatif bagi pemenuhan kebutuhannya, dikarenakan adanya motivasi/rasa bangga untuk berbuat yang terbaik demi kepentingan bangsa. 


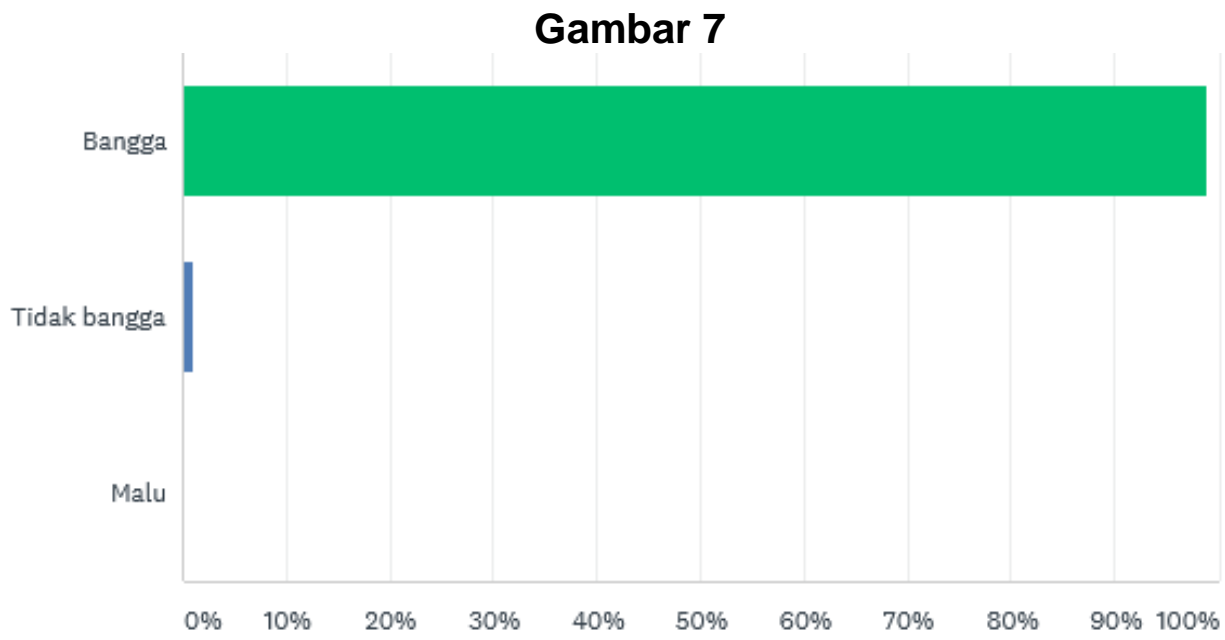

Sumber: olahan data penulis

\section{KESIMPULAN}

Dari hasil olahan data penelitian, maka kesimpulan sementara yang dapat di tarik adalah : Pertama, potret nasionalisme yang kuat di perlihatkan oleh elit pemuda di Provinsi Riau. Hal ini tentu memunculkan optimisme bahwa generasi muda di Provinsi Riau memiliki rasa kebangsaan yang tinggi. Kedua, walaupun rasa nasionalisme yang tinggi diperlihatkan oleh elit pemuda di Provinsi Riau, akan tetapi tetap di bayangbayangi oleh sejumlah kondisi yang dapat mengancam nasionalisme elit pemuda. Ancaman tersebut berupa pengaruh globalisasi kapan saja dapat menurunkan nasionalisme seseorang, terlebih lagi dengan kondisi Riau yang secara geografis berbatasan dengan beberapa negara dan Selat Malaka. Potensi menurunnya rasa nasionalisme seseorang akibat arus globalisasi tidak dapat dianggap remeh. Perlu upaya secara terus menerus dalam rangka memberikan pemahaman dan menangkal akibat buruk yang ditimbulkan dari globalisasi.

\section{REFERENSI}

Bangkit, Joned WL, 2013. Kebijakan Penanaman Nilai-nilai Nasionalisme pada Siswa di SMA Ambarawa : Skripsi Universitas Negeri Semarang 
Bungin, Burhan. 2003. Analisa Data Penelitian Kualitatif : Pemahaman Filosofis dan Metodologis Ke Arah Penguasaan Model Aplikasi. Jakarta : Raja Grafindo Persada.

Hariyanto. 2010. Etika Perjuangan Kaum Muda. Jakarta: Asisten Deputi Pemberdayaan Lembaga Kepemudaan Deputi Bidang Pemberdayaan Pemuda Kementerian Pemuda dan Olahraga.

Ibranur, Aspian. 2014. Seri Pemberdayaan Pemuda III: Pemuda Bangkit Indonesia

Bahagia. Jakarta: Asisten Deputi Bidang Organisasi Kepemudaan Deputi Bidang Pemberdayaan Pemuda Kementerian Pemuda dan Olahraga.

Musthopa, Arif. 2011. Nasionalisme Elit Pemuda. Jakarta: Yayasan Genta Hati. - 2014.Rekomendasi dan Siasat: Kemenpora dan Pemuda Menuju

Revolusi Mental. Jakarta: Asisten Deputi Bidang Organisasi Kepemudaan Deputi Bidang Pemberdayaan Pemuda Kementerian Pemuda dan Olahraga.

Perry, Marvin. 2013. Peradaban Barat : Dari Revolusi Prancis Hingga Zaman Global (terjemahan), Bantul : Kreasi Wacana

Saksono, Gatut. 2017. Pancasila Soekarno. Yogyakarta: Raja Grafndo Persada

Sarwono, Sarlito W, 2008. Psikologi Remaja, Jakarta : Raja Grafindo Jakarta

Shafer, Boyd C. 1955. Nationalism Myth and Reality, New York :A Harvest Book Harcout

Sujatno, Adi. 2012. Peranan Pemuda dalam Bingkai Wawasan Kebangsaan. Jakarta: Lembaga Ketahanan Nasional Republik Indonesia.

Syukur, Abdul. 2008. Perekat Bangsa, Pengakuan Sejarah Kepemudaan Indonesia. PT. Jakarta: Intimedia Cipta Nusantara,

Ula, Zaenul. 2014. Pemuda dan Politik (Refleksi Terhadap Peran Politik Pemuda). Jakarta: Asisten Deputi Bidang Organisasi Kepemudaan Deputi Bidang Pemberdayaan Pemuda Kementerian Pemuda dan Olahraga.

Wahyuni, Alida. 2010. Pemuda Sebagai Agen Perubahan. Asisten Deputi Pemberdayaan Lembaga Kepemudaan Deputi Bidang Pemberdayaan Pemuda Kementerian Pemuda dan Olahraga, Jakarta. 